\title{
Bringing the policy in: a new typology of national referendums
}

\section{Nanuli Silagadze ${ }^{1} \cdot$ Sergiu Gherghina ${ }^{2}$}

Published online: 19 December 2019

(c) The Author(s) 2019

\begin{abstract}
Scholarship has categorized referendums predominantly along their procedural and institutional features. This paper moves beyond these formal dimensions, argues that the policy subjected to a popular vote is the missing link and proposes a complementary typology based on the policy areas. This typology fosters comparisons across countries, political systems and over time within one policy area, thus serving as a powerful analytical tool for further analyses. At the same time, the typology maps out the history of referendum use showing the chronology of salient issues in different societies. The empirical evidence draws on an original dataset of 630 nationwide referendums in Europe between 1793 and 2019.
\end{abstract}

Keywords Europe $\cdot$ Policy $\cdot$ Referendum $\cdot$ Typology

\section{Introduction}

Over the last two decades, the literature on referendums flourished to reflect the increasing use of direct democracy around the world. Scholars developed new analytical tools and attempted to look beyond single-case studies. Comparative analyses require, among others, the possibility to assess referendums on the basis of their features, to be able to draw meaningful conclusions about their similarities and differences. To this end, several authors offered typologies to capture the essence of direct democracy in general and of referendums in particular (Uleri 1996; Beramendi et al. 2008; Kaufmann et al. 2010; Altman 2011; Svensson 2011). However, there are two major problems with these typologies. First, they are designed exclusively around

Nanuli Silagadze

nsilagad@abo.fi

Sergiu Gherghina

sergiulor@yahoo.com

1 Social Science Research Institute (SAMFORSK), Åbo Akademi University, Turku, Finland

2 Department of Politics, University of Glasgow, Glasgow, Scotland, UK 
the institutional characteristics of the popular vote (e.g. binding vs. non-binding, mandatory vs. facultative, top-down vs. bottom-up) and limit the scope of analysis. Second, this focus on procedures rather than substance partially decouples the existing typologies from the main directions of research on referendums that focus on substantive issues: the causes for their introduction, functioning and consequences (Altman 2011; Geissel and Newton 2012; Gherghina 2017; Qvortrup 2014b).

This article aims to bridge the divide and suggests a typology that has at its core the topics and policy areas subjected to vote in referendums. Over time, the topics subjected to popular vote are repeated throughout the world and some are more common than others. However, in the absence of a typology about topics, researchers cannot identify trends or compare referendums organized on the same topic. To date, there is no comparative analysis of the policies subjected to national-level referendums in Europe throughout history. The only partial exception is the coding of policies subjected to Swiss federal referendums, which has several important limitations (see the following section). The possibility to compare topics across referendums can bring several contributions to the study of referendums. The theoretical contribution is the provision of an analytical framework with broad applicability. Although built on the basis of empirical evidence in Europe, this typology can travel without conceptual stretching to other parts of the world. On methodological grounds, it provides a parsimonious way to understand referendums in terms of their content and thus enhances comparative analysis across countries, political systems and time. On the empirical side, this typology serves as a tool to identify the topics on which referendums were called throughout history. Moreover, it provides an indication about how some policies were more salient than others at different moments in time, allowing researchers to assess the impact that these policies could have on the democratic process. In addition, this typology allows to investigate the existence of a mimetic effect in which countries using referendums on a particular policy inspired other countries to do the same.

We proceed inductively and analyse the content of all national referendums organized in Europe between 1793 and 2019 (the most recent referendums were held in the Republic of Moldova about parliamentary reform, in February 2019). We clustered the topics for these 630 referendums into 12 categories that form a solid basis for further research. The remainder of this article proceeds as follows. The first section reviews the existing typologies and highlights their limitations. The second section presents the steps taken to develop this typology, describes the data and illustrates its practical merits. Next, we discuss the theoretical, methodological and empirical benefits of this typology. The concluding section wraps up by examining the potential implications of the new approach and avenues for future research.

\section{Existing typologies and their limitations}

Despite the increasing use of referendums worldwide and growing academic interest towards this subject, there is no consensus about the meaning of the term referendum or on (components of) direct democracy. Earlier research defined direct democracy as 'a regime in which citizens as a whole debate and vote on the 
most important decisions, and where their vote determines the action to be taken' (Budge 1996), as 'the right of citizens to be directly involved in political decision-making' (Kaufmann et al. 2010). Similarly, Altman (2011) defines a mechanism of direct democracy as 'a publicly recognized institution wherein citizens decide or emit their opinion on issues - other than through legislative and executive elections-directly at the ballot box through universal and secret suffrage'. A referendum is 'the opportunity for electors to participate in a decision-making process by voting on an issue more or less specific and determined' (Uleri 1996). Thus, 'in a referendum, a mass electorate votes on some public issues' (Butler and Ranney 1994) and 'a referendum is held when people cast a vote to accept or reject a question of law or policy, such as whether to amend a constitution or a piece of legislation' (Williams and Hume 2010). Another scholarly debate is on the term plebiscite. Uleri (1996) states that 'general agreement on the distinction between plebiscite and referendum is lacking'. For the Initiative and Referendum Institute Europe (IRI), plebiscites 'are procedures which citizens cannot initiate, and whose use lies exclusively within the control of the authorities. This distinction between plebiscites and referendums is fundamental for a proper understanding of direct democracy' (Kaufmann et al. 2010). As a possible solution for avoiding negative connotations with the term plebiscite, Svensson (2011) suggested replacing the term with the more neutral 'popular vote called by the authorities'.

As noted above, referendum is an ambiguous term which includes various types of votes. The existing typologies reflect the aforementioned dis-consensus over conceptualization, and scholars suggest their own classifications, often derived from the experiences and peculiarities in their own countries (Uleri 1996; Beramendi et al. 2008; Kaufmann et al. 2010; Altman 2011; Svensson 2011). They can hardly agree on the number of referendum types and criteria to be employed. For example, using different criteria Magleby (1984) identified four types of referendums, Auer (1989) suggested five types, Möckli (1994) distinguished between six types and Suksi (1993) identified 12 types. Although authors tend to use different terms for the same procedure, a common denominator is ubiquitous across all typologies - the institutional design. Main variations in the types of direct democracy are structured along two questions: who initiates the referendum and whether the vote is mandatory or not (Uleri 1996).

The typology developed by the International Institute for Democracy and Electoral Assistance (IDEA) identifies four broad types of direct democracy-referendums, citizens' initiatives, agenda initiatives and recall. Consistent with Uleri (1996), this typology distinguishes between mandatory and optional referendums (initiated by the authorities). The IDEA typology differentiates between citizens' initiative and the citizen-demanded referendum. Citizens' initiative (also called a 'popular initiative') refers to a new piece of legislation wherein a number of citizens present a political proposal (e.g. draft legislation), obtain a required number of signatures for its support and thereby force a popular vote (referendum) on the issue. A citizen-demanded referendum is related either to existing laws- the abrogative referendum; or to a newly accepted piece of legislation-the rejective referendum. Agenda initiative is the only procedure that does not necessarily lead 
to a referendum. The agenda initiative places an issue on the political agenda and requires the legislature to consider and/or act on a proposal (Beramendi et al. 2008).

The classification elaborated by the IRI sees direct democracy as votes on substantial issues, not on people, thus excluding recall. Furthermore, for the IRI the distinction between top-down and bottom-up procedures is crucial, since direct democracy should empower people, not governments, suggesting to categorize plebiscites as a part of representative rather than direct democracy (Kaufmann et al. 2010).

In his attempt to provide analytical dimensions to differentiate between referendums, Altman (2011) provides a typology based on four criteria. The first criterion is whether the mechanism is legally regulated by law or the constitution: mandatory versus facultative. The second involves whether the result of the vote is absolute. Altman follows the common terminology and refers to a dichotomy between binding and consultative votes. The third criterion refers to the purpose of the procedure: whether it aims to alter the status quo (proactive) or attempts to sustain the status quo (reactive). The final criterion deals with the trigger of direct democratic procedure: initiated by the political establishment (top-down) versus citizen-initiated (bottom-up). Along similar lines, the typology of direct democratic votes becomes somewhat simpler by including only four types of votes: mandatory referendums, popular votes called by authorities, popular votes called by citizens (on a newly passed or existing law) and citizens' initiatives (Svensson 2011).

Several authors developed their own (usually rather short) categorization based on the type of referendums analysed in their research. For instance, Christin and Hug (2002), studying mainly referendums on the EU integration, differentiate between required (or mandatory), non-required passive (launched by the government) and non-required active referendums (launched by actors outside government). Tridimas (2007) highlights three main institutional features of a referendum: binding versus consultative; on constitutional versus post-constitutional issue (e.g. on ordinary laws like taxation) and required by the constitution (mandatory) versus non-required. In one of the more recent studies, there is a difference between initiatives, constitutional referendums, citizens' referendums, facultative referendums and plebiscites (Qvortrup 2014b).

The most recent typology of referendums was suggested by Mendez and Germann (2018), inspired by the study of sovereignty referendums. It is based on two dimensions: the scope (sub-national, national, supra-national) and logic (integrative vs. disintegrative). Notably, the applicability of this typology is rather limited due to its focus on the single issue of sovereignty. Consequently, we can use this typology as an explanatory tool for only few types of referendums (EU, independence and, in some cases, constitutional).

\section{A policy-based approach}

The previous section reflects the academic efforts made to classify referendums according to different criteria. These typologies delineate the institutional characteristics of referendums (e.g. binding vs. non-binding, mandatory vs. facultative, and top-down vs. bottom-up) but devote limited space to their substance, i.e. 
the policy. This is rather surprising since policy submitted to a vote is one of the defining features of referendums. Even semantically, the word 'referendum' refers to popular votes on a policy issue (Qvortrup 2017). Accordingly, in order to avoid further misunderstanding and in alignment with the semantics of the word, 'referendum' is used in this article as a popular vote on a policy issue, thus comprising of all votes that were initiated either by the elite (top-down referendums, plebiscites), by citizens (popular initiatives, abrogative or rejective referendums) or were launched automatically in accordance with the country's constitutional provisions (mandatory).

The policy-oriented approach has been partially applied to particular types of referendums. For instance, earlier studies analysed the EU/NATO membership referendums - separately from other types of referendums-and across different countries, finding similarities and country-specific aspects (Hobolt 2007, 2009; Mendez et al. 2014; Qvortrup 2016). In a similar way, constitutional referendums received special attention (Tierney 2012; Anckar 2014). Analogously, ethnic/sovereignty referendums received distinctive attention from the scholarship (Qvortrup 2014a; Mendez and Germann 2018). Furthermore, there are some isolated studies on fiscal/budget referendums and their effects, mainly in Switzerland and the USA (Feld and Matsusaka 2003; Kriesi 2012). LeDuc (2003) differentiates between four types of referendums: on constitutional issues, treaties and international agreements, on sovereignty and on public policy. He acknowledges that these categories are not mutually exclusive and 'nevertheless useful for a general understanding of the kinds of issues on which citizens of democratic nations are most often called upon to vote'. The category 'public policy' is fairly broad, including a wide variety of topics from abortion to environmental issues and citizenship laws. Thus, existing scholarship has not developed further the policybased approach in order to cover the full range of referendums.

There are only two typologies accounting for the full range of policies voted upon in referendums in two countries: Switzerland (Linder et al. 2010) and Liechtenstein (Marxer 2018). Apart from the fact that these sources are available exclusively in German, they both have several shortcomings, derived from the fact that they are constructed based on the experiences of a single country, being embedded in the particular national and institutional context. For example, there is limited empirical diversity stemming from the actuality that some major policies on which many referendums were carried out in Europe are not included in the Swiss (e.g. constitution and state formation) or Liechtenstein typology (e.g. foreign affairs). Furthermore, due to the tradition of Swiss referendums, this typology merges culture, religion and media into one policy field, whereas the Liechtenstein typology sees infrastructure, spatial planning and building laws as three separate categories and devotes a distinct policy field to recreation, hunting and fishing. More importantly, the drawback of these typologies is the assignment of referendums to multiple categories simultaneously, which raises both methodological and empirical problems. Thus, due to a very detailed division of policy issues and an absence of some major categories, these two typologies remain country-specific and not replicable on a larger scale. 


\section{Towards a new typology: data and policies}

This typology was developed inductively, after scrutinizing all national-level referendums in Europe, covering a time period of more than two centuries (1793-2019). The dataset that we use for the analysis is original, compiled from primary sources and includes 630 referendums organized in 48 countries and territories. ${ }^{1}$ The number of referendums varies greatly across countries, as 'Appendix 2' shows.

We conceptualized referendums as one issue subjected to a popular vote, i.e. the answer to one question. If more issues or questions are addressed, then we viewed those as different referendums, although they may be organized at the same time. For example, the 2016 constitutional referendum in Azerbaijan included 27 separate questions. Consequently, we considered that vote as 27 different referendums and categorized each under different policy fields. The analysis includes a diverse range of countries: former/no more existing states (Czechoslovakia, the Soviet Union), states with the longest history of democracy (e.g. San Marino since 1600, Liechtenstein since 1921), consolidated democracies (Denmark, France, Italy, etc.), transition countries (Albania, Georgia, Macedonia, etc.) and authoritarian regimes (Azerbaijan, Belarus etc.). We included referendums in all these types of regimes to allow for a broader comparison and to avoid bias. Established democracies are only a part of the universe of cases, and the focus on them is equivalent to loosing important data and overlooking explanatory variables.

We did not include referendums from Switzerland due to the fact that the country, with its longest and intensive tradition of direct democracy, is rather an exception than a rule in Europe. Swiss citizens voted in ca. 600 referendums in the same period of time; thus, that would distort the overall results. Furthermore, the analysis does not cover the referendums in conflict or internationally non-acknowledged areas (Donetsk, Crimea, Ossetia, Abkhazia, Northern Cyprus, etc.). In addition, if a country, at the moment of a popular vote, was part of a different state, it is not in the analysis, e.g. Romania in 1864 (which held a referendum on Constitution and electoral law) was officially part of the Ottoman Empire and thus, we excluded it from the dataset. Neither do we incorporate unofficial/private referendums-e.g. Italy in 2007 as trade unions and the government organized a referendum where only employees, unemployed and pensioners were called to vote (approximately 15 million out of the total electorate of approximately 50 million).

\footnotetext{
1 The dataset includes the following countries and territories: Albania, Andorra, Armenia, Austria, Azerbaijan, Belarus, Belgium, Bosnia-Herzegovina, Bulgaria, Croatia, Cyprus, Czech Republic, Czechoslovakia, Denmark, Estonia, Finland, France, Georgia, Greece, Hungary, Iceland, Ireland, Italy, Latvia, Liechtenstein, Lithuania, Luxembourg, Macedonia, Malta, Moldova, Monaco, Montenegro, Netherlands, Norway, Poland, Portugal, Romania, Russia, San Marino, Serbia, Slovakia, Slovenia, Soviet Union, Spain, Sweden, Turkey, Ukraine and the United Kingdom.
} 


\section{Why an original dataset}

Our dataset addresses the major shortcomings of existing databases that are inconsistent in their coding and incomplete. The following lines briefly summarize the problems of the two most comprehensive databases for referendums. The Database and Search Engine for Direct Democracy (www.sudd.ch) is not reliable in the classification of referendum types and their results. There are important factual errors with misclassification of referendums. For example, the classification of 2016 Italian referendum as a citizens' initiative when the prime minister initiated it. Similarly, the database views the 1997 Hungarian referendum and the 2003 Polish referendum as top-down votes instead of mandatory; the 2016 Bulgarian referendums as binding when this was relative to the turnout (valid votes); the 1996 referendum in Poland and the 2016 referendum in Liechtenstein as adopted when they both failed, etc.

The database of the Centre for Research on Direct Democracy (www.c2d.ch) is incomplete: several tens of referendums are missing (e.g. Italy 1929 and 1934, Andorra 1933, Austria 1938, Romania 2009, Slovenia 2015, Bulgaria 2016, Netherlands 2016, UK 2016, etc.). Other referendums where two different initiatives were put to a vote are marked as one (e.g. Liechtenstein 2003, 2014). The binding label is absent, while the category 'institutions' does not shed light on the initiator. Another database is the Navigator of Democracy International (www.democracy-internatio nal.org/de/navigator), which is very useful for the legal provisions and requirements for direct democracy practices worldwide. However, its focus is on the availability of these practices rather than accounting for actual popular votes that have taken place so far. As such, it does not present the policies that have been voted upon.

To overcome these shortcomings, we synthesized multiple sources to compile a more advanced dataset. On average, we used seven different sources, comparing and contrasting the information for each referendum: primary sources, including country-specific databases, country reports and analyses, constitution or special law texts (for turnout and approval quorum), newspaper articles, online publications, official statements, or academic texts (encyclopaedias, volumes, research articles) devoted to the thorough analysis of particular countries. We tried to identify independent sources, i.e. no cross-referencing, and we applied systematically the same strategy for situations in which the information collected was contradictory. In an attempt to increase the reliability of our data, we sought to find as many sources as possible and chose the most common piece of information encountered in these sources, giving priority to primary documents. When no information was available (e.g. Liechtenstein), we asked country experts in the field of direct democracy about particular referendums and requested sources. Most information was available in English, German or Russian, and we used translations for the few remaining referendums (e.g. Azerbaijan 2009, 2016).

As illustrated by the examples of referendum topics ("Appendix 1"), these policy categories are quite broad, meant both to cover a variety of topics and simplify their categorization. To avoid the double categorization of referendums, we placed the topic in the category to which it primarily belongs, looking at the substance of the intended policy. Questions regarding abortion, divorce or death penalty are about morality and ethics but also about constitution (in those cases in which it entails 


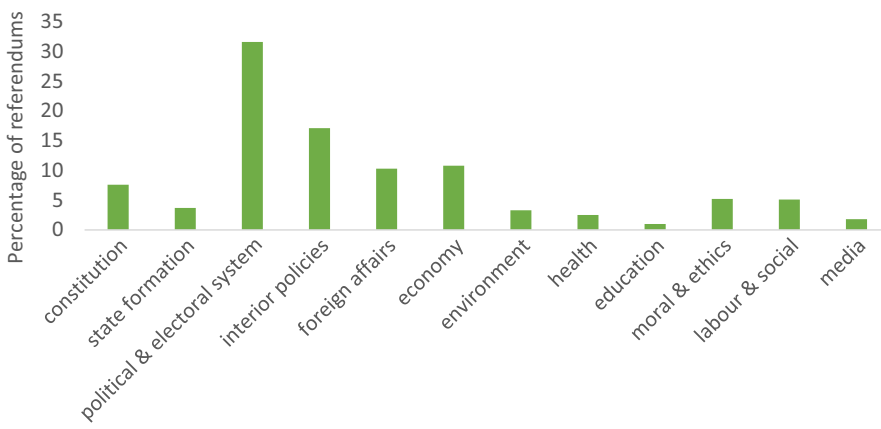

Fig. 1 The frequency of policy areas used in referendums (1793-2019)

an amendment) or interior policies. Similarly, nuclear energy is about environment, but also about economy since it involves costs and revenues. Another example is that of electoral reforms which require economic resources for their implementation (administration, organizational costs).

To limit the bias of our judgment and test the coding robustness, we asked several scholars working in the fields of direct democracy or public policy, from different countries and at different stages of their careers, to run an independent coding of the dataset that we provided. This involved assigning referendums to one of the 12 policy areas outlined in Fig. 1 and "Appendix 1". The inter-coder reliability test that we conducted after receiving all of their coding sheets demonstrated a high level of convergence (Krippendorff's alpha $=0.837$ ), and thus, we feel confident in our coding.

\section{Policy categories}

After a thorough analysis of the referendums conducted so far in Europe, we identified 12 categories of policies subjected to public vote ("Appendix 1"). Some were more used than others, and Fig. 1 presents their frequency in percentages calculated from the total number of referendums organized between 1793 and 2019 at the national level $(N=630)$. The most used topics in referendums belong to political/electoral systems (almost one-third) and interior policy (almost 17\% of the total number). Together, these two policy areas amount to approximately $50 \%$ of all referendum topics. At the other extreme, the less used topics are in the areas of education, media and health, amounting to approximately $5 \%$ all together. To get a better understanding of how we conceptualize them, each of the policy areas is briefly explained in the following paragraphs. We present the policy areas in a relatively chronological order of their use in referendums. For example, we start with constitutional policies because this was the first one on which a referendum was initiated in 1793.

The constitutional category includes all referendums on adoption of a new constitution or on approval of constitutional reform regarding major changes (for instance, the 2016 referendum in Italy or the 2017 referendum in Turkey). We cluster all other cases where certain constitutional issues were put on ballot according to the field of 
policy since, for instance, in Ireland all referendums belong formally to "constitutional referendums'. However, they refer to diverse policy fields: from abortion and same-sex marriage to EU Treaties. Thus, we look in detail at what the amendment was about and categorize it according to the topic. Dissolving this category of 'constitutional referendums' helps achieve a more nuanced overview of different policies that have ever been voted on.

State formation includes all referendums on independence (e.g. independence referendums in former Soviet republics in the early 1990s); referendums on whether an entity should remain part of a state (Croatia 1991 on remaining within Yugoslavia) or become part of another state (Danish referendum in 1920 on acceptance of North Schleswig); referendums on a new territorial composition of a state (2004 referendum on Foundation of a Reunified Republic of Cyprus) or on the continued existence within the same territory (the Moldovan referendum in 1991 on the continued existence of the Soviet Union in 1991).

The referendums on the political system refer to popular votes about the form of government (Greece 1974 on retaining monarchy); distribution of power (Belarus 1995 on the president's power to dissolve parliament); the introduction or abolishment of new political institutions (Iceland 2012 on introduction of initiatives, Ireland 2013 on abolishment of Senate), and electoral system issues (Slovakia 2010 on introduction of electronic voting, Luxembourg 2015 on lowering the voting age from 18 to 16 ).

The interior policy referendums include popular votes on basic rights (Liechtenstein 1985 equal rights for men and women); laws on citizenship (Hungary 2004 on dual citizenship); particular regulations (Malta 2015 on spring bird hunting, Sweden 1955 on traffic regulations); legal framework (Denmark 1963 on land law reform); or administrative reorganization (Italy 1997 on the abolition of the Ministry for Agriculture and Fishery).

The foreign affairs category includes all topics of interstate relations, such as: border/territory issues (Denmark 1916 on sale of West Indian Islands to the USA); international arrangements (France 1962 Evian Accords ending Algerian War, Lithuania 1992 withdrawal of Soviet Troops); international collaboration (Belarus 1995 economic collaboration with the Russian Federation, Luxembourg 1919 Economic Union with France or Belgium). This policy category is dominated by referendums related to the issue of EU integration and NATO membership for which more than 30 referendums were organized, inter alia: Norway 1972 on accession to the European Economic Community, Denmark 2000 on the introduction of Euro, Georgia 2008 on NATO membership.

The economy category brings together the issues that are related to economic or financial measures (Greece 2015 on accepting bailout conditions of EC, ECB and IMF); Poland 1997 on economic reforms); distribution of resources (Lithuania 1996 on allocating half of the state budget for social issues, health and culture); ownership issues (Iceland 2012 on public ownership of natural resources, Poland 1996 on a privatization program); on public expenses (San Marino 2016 on capping public sector salaries at $100,000 €)$.

The environment category includes referendums on nuclear plants (Austria 1974, Bulgaria 2013), general policies concerning the environment (Italy 2016 on oil and 
natural gas drilling, Liechtenstein 2002 on a sustainable transport policy). Health policies refer to specific issues (Finland 1931 on an alcohol policy, Liechtenstein 2009 on the Tobacco Control Act) or to general issues about the healthcare system (Hungary 2008 on the abolition of fees for ambulatory treatments). The education policies refer to both higher education (Hungary 2008 on the abolition of fees) and school policies (Estonia 1923 on restoring voluntary religious education in state schools, Slovakia 2015 on children's right to skip classes involving education on sex and euthanasia). The relatively broad category of family, ethics and moral issues includes referendums on same-sex marriage (Ireland 2015), divorce (Malta 2011), abortion (Portugal 2007), the death penalty (Belarus 1996) and other moral issues (Italy 2005 on embryonic research).

The labour and social issues include referendums on labour regulations (Slovenia 2011 on part-time work law, San Marino 2008 on the abolition of temporary employment contracts), pensions (Sweden 1957 on pension reform), trade unions (Italy 2000 on the abrogation of automatic salary deduction for trade unions and worker associations), social policies (Liechtenstein 1967 on increasing child benefits and family allowances). The media category includes all referendums on broadcasting rights (Italy 1995 on repealing the law allowing advertising breaks during television programs, Slovenia 2010 on the law regarding public broadcaster RTV Slovenija) and further regulations related to media landscape (Italy 1997 on the abrogation of the Association of Journalists, Liechtenstein 1930 on media law).

\section{The relevance of this typology}

Every policy subjected to popular votes brings a package of attributes. For example, the referendums on abortion, on a new nuclear plant or on the EU/NATO membership set completely different argumentation lines. These lines result in different modes of campaigning, involved actors, perceived political pressure for parties (as a result of societal saliency and campaign position) and different degrees of emotions. These factors are derived from the very nature of the policy type which seems to serve as a complementary tool for the better understanding of why some issues are put to a referendum and how the vote is influenced or decided. They also reveal the importance of examining the policies when attempting to understand the existing types of referendums. The classification suggested in this article offers a more precise and complete picture of referendums, taking into account all the nuances characteristic to each topic. This typology bears three major benefits: theoretical, methodological and empirical.

At a theoretical level, this policy-based typology serves as an innovative analytical framework that can be used to map the policies put on ballots across the world. Thus, it allows an observation of what kind of issues dominate the public discourse in a society, on a continent, and during a certain time period. Mapping policies across a given territory is useful because it could provide a deeper understanding of how and why the referendums were used, the actors involved and the degree of saliency according to the type of policy on ballot. In this sense, this typology provides 
a new set of explanatory variables that could be of real value in future research. More specifically, it accounts for contextual explanations in the referendum process that go beyond historical or country-specific peculiarities. For instance, one could observe how political leaders from different countries 'copied' or benefited from the experiences with direct democracy in their neighbouring states (e.g. mimetism and the contagion effect). This method elucidates topic-specific determinants and enables researchers to see the bigger picture of referendums' use.

At the same time, our typology bridges two strands of literature: categorization of referendums along institutional features and substantial research of causes, consequences and process of popular votes. With this typology, we link the use of referendums with its institutional features. For example, almost half of the referendums on moral and ethical issues (47\%) were bottom-up, while the overwhelming majority of constitutional referendums (94\%) are either mandatory or top-down. Furthermore, this typology has the potential to advance the democratic theory, by looking at the topics that were subjected to votes and their effect on, for instance, legitimacy or satisfaction with democracy as a whole. It sheds light on the policy-determined variations in participation or success rates.

From a methodological perspective, this typology offers the possibility of comparing and contrasting referendums on the basis of their content. This classification allows comparisons between policies, countries (within the same policy) or over time to detect patterns. With such advantages at hand, this typology tests the existence of interconnections between policies and enables comparisons between various cultures, political systems and time periods. Furthermore, the typology unveils trajectories or presents similarities between referendums to which earlier classifications are not sensitive. For example, it can indicate how referendums within a policy area developed (how popular they became over time) and how specific issues arose over time. In brief, this policy-oriented approach can expand the scope of comparisons and enhance a broad range of conclusions that were not accessible to scholars and the broader public until now. Equally important, the typology provides a straightforward and comprehensive possibility to classify further referendums according to their policies. These 12 policy categories are not context or time sensitive and can travel across regions.

Empirically, the typology illustrates important similarities and differences between the policies subjected to vote in referendums. The policy categories serve an analytical function through which scholars become aware of the details they should emphasize to understand it. Referendum initiators, who are either politicians or citizens, will better understand how to approach a popular vote in the policy area of their proposal. For example, those who are willing to initiate a referendum on health issues can be inspired by previous practices in countries in which such referendums were carried out. The typology may build a bridge between academics and policymakers by identifying common rules, and drawing recommendations and lessons from prior experiences on a specific topic throughout history. At the same time, the typology is another way of revealing the salient issues in different societies from the European continent at various moments in time. The policies subjected to referendums could reveal an important match with the political and historical events 


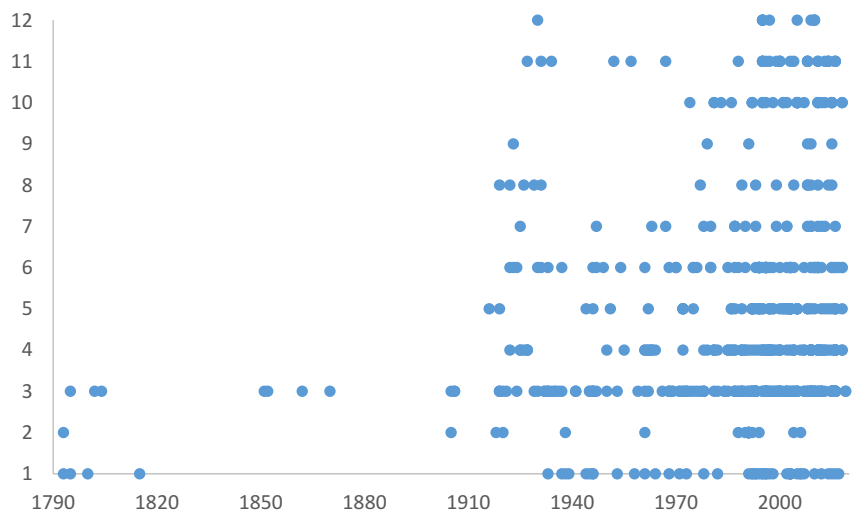

Note: 1 = constitution; 2 = state formation; 3 = political \& electoral system; 4 = interior policies; $5=$ foreign affairs; $6=$ economy; 7 = environment; $8=$ health; $9=$ education; $10=$ moral $\&$ ethics; $11=$ labour \& social; 12 = media.

Fig. 2 The distribution of referendums according to their policy in Europe (1793-2019). Note $1=$ constitution; $2=$ state formation; $3=$ political and electoral system; $4=$ interior policies; $5=$ foreign affairs; $6=$ economy; $7=$ environment; $8=$ health; $9=$ education; $10=$ moral and ethics; $11=$ labour and social; $12=$ media

on a given territory. For example, the referendums on state formation coincide with major periods of turmoil in European history.

Figure 2 presents the longitudinal distribution of referendums between 1793 and 2019 for each policy category. The clustering of referendums according to policies indicates what issues dominated the public discourse in a certain time period. This approach fosters comparisons within and between policy areas. For example, within the same policy area, a close look at the referendums on moral and ethical issues reveals that they emerged quite late in the history of European direct democracy, but their distribution is fairly balanced across time from their first use until now. In the case of state formation referendums, they were among the first direct democracy votes to be cast as early as 1793 , but the longitudinal perspective indicates a high concentration around the 1990-2010 decades when many countries in post-communist Europe declared their independence.

The comparisons between policy areas show important differences in terms of dispersion. For example, the referendums on constitution adoption or change come in waves, while those on the political and electoral system have a relatively uniform distribution. Quite a few policy areas (e.g. economy or labour and social) have temporal clusters that could inspire analyses along the lines of contagion effects in which some countries followed the examples of others in subjecting a specific topic to referendums. This mapping also illustrates the chronology of salient issues in society. Constitution, state formation and political system matters were subjected first to referendums, and they made their exclusive subject until 1919 when Denmark organized a referendum on foreign affairs (about the sale of the West Indian Islands to the USA). Whereas the referendums on moral and ethical issues emerged quite late in the history of European direct democracy, but their distribution is fairly balanced across time from their first use until now. 


\section{Conclusions}

This article aimed to propose a new policy-based typology of referendums that could enhance meaningful and straightforward comparisons between referendums. Previous typologies are built along institutional features and ignore, to a great extent, the core of popular votes, i.e. the policy. The dataset used to construct this typology covers 630 referendums in 48 countries over a period of 226 years and uses 12 policy areas. It maps out the historical path of referendum use, identifies specific trajectories and offers a holistic (and nuanced) picture of referendums. The typology allows for discovering what kind of issues dominated the public discourse in Europe at different moments in time.

Through its parsimonious analytical dimensions, this typology illustrates that it would be a mistake to rely on an excessively high number of referendums. The policies subjected to popular vote can be clustered into several categories without losing their content and, at the same time, increasing comparability. The broad applicability of these categories and their theoretical basis could lead scholars to attempt to categorize new referendums into established categories and thus to increase the number of units of analysis within the same framework. Furthermore, the typology presented here is fully reflective of the real variation in referendums in Europe and should facilitate future testing of the hypotheses about the causes, forms, functions, evolutionary trajectories and consequences of referendums in different social, political, technological and cultural contexts.

Since policy data are available for all referendums, the typology can be used in comparative research both as a dependent variable to uncover the factors that could explain the variation in policies subjected to referendums and as an independent variable to study the effects of different policies on the political system, legitimacy or democratic performance. For example, one avenue for research is the policy's effect on the success of the referendum-which policies tend to be adopted and which rejected. The policy's effect can serve as an alternative explanation to the institutional or campaign determinants that were examined in earlier studies. The development of this new typology is one further step in understanding the complexity of direct democracy as the interaction between citizens, state institutions and decision-making. Although the results presented here are encouraging, there is room for improvement about the operationalization of policies and the scope for comparison. Related to the latter, another avenue for research could be a comparison between the national-level referendums in Europe and those in Switzerland. This would allow us to examine whether a typology based on the experience of many European countries can be applied to a national setting where referendums are used extensively.

Acknowledgements The authors are grateful to the members of the Comparative Politics Cluster at University of Glasgow and to Lisa Blazo for their careful reading, excellent suggestions and constructive criticism on earlier versions of this article.

Open Access This article is licensed under a Creative Commons Attribution 4.0 International License, which permits use, sharing, adaptation, distribution and reproduction in any medium or format, as long as you give appropriate credit to the original author(s) and the source, provide a link to the Creative Commons licence, and indicate if changes were made. The images or other third party material in this article 
are included in the article's Creative Commons licence, unless indicated otherwise in a credit line to the material. If material is not included in the article's Creative Commons licence and your intended use is not permitted by statutory regulation or exceeds the permitted use, you will need to obtain permission directly from the copyright holder. To view a copy of this licence, visit http://creativecommons.org/licen ses/by/4.0/.

\section{Appendix 1: Policy categories, their conceptualization and empirical correspondence}

\begin{tabular}{|c|c|c|}
\hline Policy category & Topics & Examples \\
\hline Constitution & $\begin{array}{l}\text { Adopt a new constitution } \\
\text { Approve a major constitutional } \\
\text { reform }\end{array}$ & $\begin{array}{l}\text { Romania 1991, Poland } 1997 \\
\text { Turkey } 2017\end{array}$ \\
\hline State formation & $\begin{array}{l}\text { Referendums on independence } \\
\text { Territories as parts of a state } \\
\text { Becoming part of another state } \\
\text { New territorial composition of a } \\
\text { state } \\
\text { Preservation of independence }\end{array}$ & $\begin{array}{l}\text { France } 1961 \text {, Norway } 1905 \text {, Soviet } \\
\quad \text { republics } 1991 \\
\text { Croatia } 1991 \text {, Iceland } 1918 \\
\text { Austria } 1938 \text {, Denmark } 1920 \\
\text { Cyprus } 2004 \\
\text { Moldova } 1994\end{array}$ \\
\hline Political and electoral system & $\begin{array}{l}\text { Form of government (monarchy, } \\
\text { republic) } \\
\text { Distribution of power } \\
\text { Representation and political } \\
\text { participation } \\
\text { Political reforms } \\
\text { Electoral system }\end{array}$ & $\begin{array}{l}\text { Albania 1997, Greece 1935, Italy } \\
1946 \\
\text { Belarus 1995, Moldova 1999 } \\
\text { Iceland 2012, Ireland 2013, Ukraine } \\
2000 \\
\text { Liechtenstein 1968, Spain } 1976 \\
\text { Andorra 1982, Georgia 2008, Lux- } \\
\text { embourg 2015, San Marino 2015, } \\
\text { Russia 1993, Slovakia } 2010\end{array}$ \\
\hline Interior policies & $\begin{array}{l}\text { Basic rights } \\
\text { Citizenry and administration } \\
\text { Legal framework on specific } \\
\text { reforms (e.g. land, weapons) } \\
\text { Minority rights }\end{array}$ & $\begin{array}{l}\text { Azerbaijan 2009, Liechtenstein } 1985 \\
\text { Austria 2013, Latvia 1998, Hungary } \\
\text { 2004, Portugal 1998 } \\
\text { Denmark 1963, Malta 2015, Sweden } \\
1955 \\
\text { Azerbaijan 2016, Belarus } 1995\end{array}$ \\
\hline Foreign affairs & $\begin{array}{l}\text { Border and territory issues } \\
\text { International arrangements } \\
\text { International collaboration } \\
\text { EU and NATO integration }\end{array}$ & $\begin{array}{l}\text { Denmark 1916, Poland 1946, Slove- } \\
\text { nia } 2010 \\
\text { France } 1962 \text {, Lithuania 1992, Slova- } \\
\text { kia } 1997 \text {, Iceland } 2011 \\
\text { Belarus } 1995 \text {, Ireland 2001, Luxem- } \\
\text { bourg } 1919 \\
\text { Georgia 2008, Denmark 2000, } \\
\text { Norway } 1972\end{array}$ \\
\hline Economy & $\begin{array}{l}\text { Economic and financial reforms } \\
\text { Distribution of resources } \\
\text { Ownership issues } \\
\text { Public expenses }\end{array}$ & $\begin{array}{l}\text { Greece 2015, Poland } 1997 \\
\text { Liechtenstein 1961, Lithuania } 1996 \\
\text { Iceland 2012, Italy } 2011 \\
\text { San Marino 2016, Slovakia } 2010\end{array}$ \\
\hline Environment & $\begin{array}{l}\text { Construction or maintenance of } \\
\text { nuclear plants } \\
\text { General policies }\end{array}$ & $\begin{array}{l}\text { Austria 1978, Bulgaria } 2013 \\
\text { Italy 1990, Liechtenstein } 2002\end{array}$ \\
\hline Health & $\begin{array}{l}\text { Alcohol and tobacco } \\
\text { Healthcare system }\end{array}$ & $\begin{array}{l}\text { Finland 1931, Liechtenstein } 2009 \\
\text { Azerbaijan 2016, Hungary } 2008\end{array}$ \\
\hline
\end{tabular}




\begin{tabular}{lll}
\hline Policy category & Topics & Examples \\
\hline Education & Higher education & Hungary 2008 \\
& School policies & Estonia 1923, Slovakia 2015 \\
Moral and ethical issues & Marriage (including same-sex) & Croatia 2013, Ireland 2015 \\
& Divorce, abortion and issues & Malta 2011, Italy 2005, Portugal \\
& related (e.g. embryonic research) & 2007 \\
& Death penalty and other & Belarus 1996 \\
Labour and social issues & Labour regulations & Liechtenstein 1931, Slovenia 2011 \\
& Pensions & Latvia 1999, Sweden 1957 \\
& Trade unions & Italy 2000 \\
& Social policies & Liechtenstein 1967, Poland 1996 \\
Media & Media regulation & Italy 1995 \\
& Broadcasting rights & Slovenia 2010 \\
\hline
\end{tabular}

\section{Appendix 2: The distribution of referendums in Europe across countries (1793-2019)}

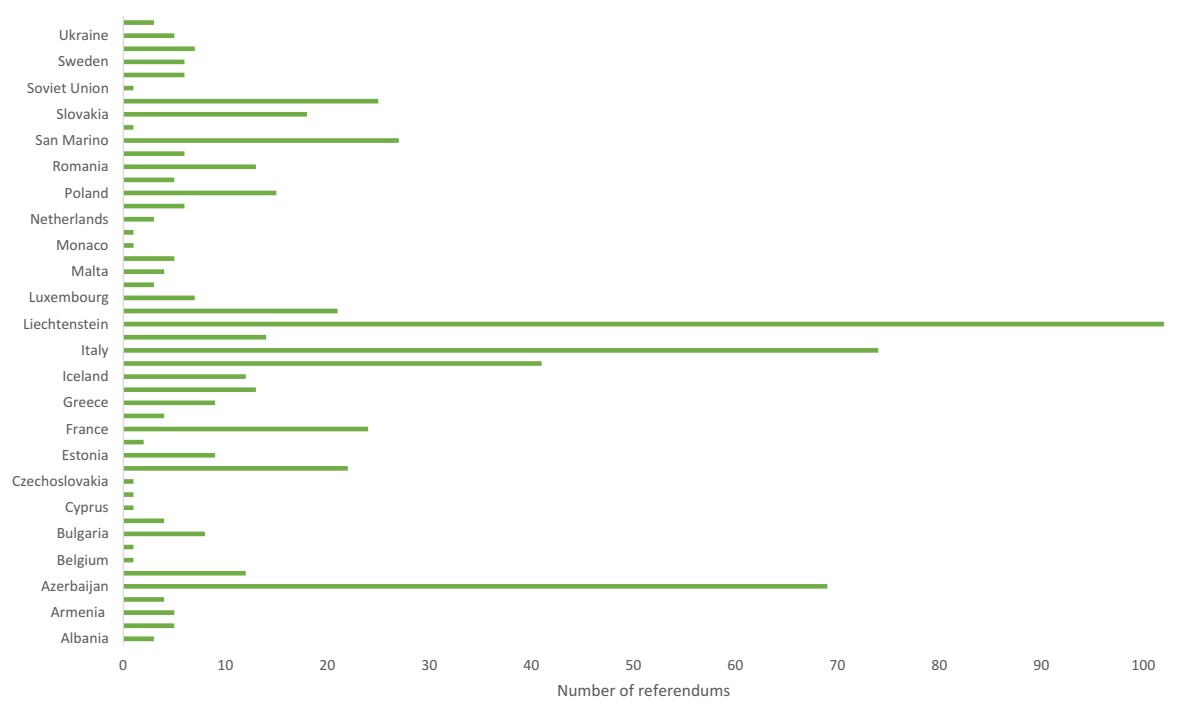

\section{References}

Altman, D. 2011. Direct Democracy Worldwide. Cambridge: Cambridge University Press.

Anckar, D. 2014. Constitutional Referendums in the Countries of the World. Journal of Politics and Law 7(1): 12-22.

Auer, A. 1989. Le referendum et l'initiative populaires aux États-Unis. Paris: Economica. 
Beramendi, V., et al. 2008. Direct Democracy: The International IDEA Handbook. Stockholm: International IDEA.

Budge, I. 1996. The New Challenge of Direct Democracy. Cambridge: Polity Press.

Butler, D., and A. Ranney. 1994. Practice. In Referendums around the World: The Growing Use of Direct Democracy, ed. D. Butler and A. Ranney, 1-10. Washington, D.C.: American Enterprise Institute for Public Policy Research.

Christin, T., and S. Hug. 2002. Referendums and Citizen Support for European Integration. Comparative Political Studies 35(5): 586-617.

Feld, L.P., and J.G. Matsusaka. 2003. Budget Referendums and Government Spending: Evidence from Swiss Cantons. Journal of Public Economics 87(12): 2703-2724.

Geissel, B., and K. Newton (eds.). 2012. Evaluating Democratic Innovations: Curing the Democratic Malaise?. London: Routledge.

Gherghina, S. 2017. Direct Democracy and Subjective Regime Legitimacy in Europe. Democratization 24(4): 613-631.

Hobolt, S.B. 2007. Taking Cues on Europe? Voter Competence and Party Endorsements in Referendums on European Integration. European Journal of Political Research 46(2): 151-182.

Hobolt, S.B. 2009. Europe in Question: Referendums on European Integration. Oxford: Oxford University Press.

Kaufmann, B., R. Büchi, and N. Braun. 2010. Guidebook to Direct Democracy in Switzerland and Beyond, 4th ed. Marburg: The Initiative and Referendum Institute Europe (IRI).

Kriesi, H. 2012. Direct Democracy: Swiss Experience. In Evaluating Democratic Innovations, Curing the Democratic Malaise?, ed. B. Geissel and K. Newton, 39-55. London: Routledge.

LeDuc, L. 2003. The Politics of Direct Democracy: Referendums in Global Perspective. Toronto: Broadview Press.

Linder, W., C. Bolliger, and Y. Rielle (eds.). 2010. Handbuch der eidgenössischen Volksabstimmungen 1848-2007 (Handbook of the federal referendums 1848-2007). Bern: Haupt Verlag.

Magleby, D.B. 1984. Direct Legislation: Voting on Ballot Propositions in the United States. Baltimore: Johns Hopkins University Press.

Marxer, W. 2018. Direkte Demokratie in Liechtenstein. Entwicklung, Regelungen, Praxis. Bendern: Verlag der Liechtensteinischen Akademischen Gesellschaft (Liechtenstein Politische Schriften, 60).

Mendez, F., and M. Germann. 2018. Contested Sovereignty: Mapping Referendums on Sovereignty over Time and Space. British Journal of Political Science 48(01): 141-165.

Mendez, F., M. Mendez, and V. Triga. 2014. Referendums and the European Union: A Comparative Inquiry. Cambridge: Cambridge University Press.

Möckli, S. 1994. Direkte Demokratie: ein internationaler Vergleich. Bern: Verlag Paul Haupt.

Qvortrup, M. 2014a. Referendums and Ethnic Conflict. Philadelphia: University of Pennsylvania Press.

Qvortrup, M. (ed.). 2014b. Referendums Around the World: The Continued Growth of Direct Democracy. Basingstoke: Palgrave Macmillan.

Qvortrup, M. 2016. Referendums on Membership and European Integration 1972-2015. The Political Quarterly 87(1): 61-68.

Qvortrup, M. 2017. Demystifying Direct Democracy. Journal of Democracy 28(3): 141-152.

Suksi, M. 1993. Bringing in the People: A Comparison of Constitutional Forms and Practices of the Referendum. Dordrecht: Martinus Nijhoff Publishers.

Svensson, P. 2011. 'Forms and Terminology of Direct Democracy', Joint conference of IPSA and ECPR in São Paulo, pp. 1-27. http://paperroom.ipsa.org/papers/paper_26306.pdf. Accessed 6 June 2017.

Tierney, S. 2012. Constitutional Referendums: The Theory and Practice of Republican Deliberation. Oxford: Oxford University Press.

Tridimas, G. 2007. Ratification Through Referendum or Parliamentary Vote: When to Call a Nonrequired Referendum? European Journal of Political Economy 23: 674-692.

Uleri, P.V. 1996. Introduction. In The Referendum Experience in Europe, ed. M. Gallagher and P.V. Uleri, 1-19. London: MacMillan.

Williams, G., and D. Hume. 2010. People Power: The History and Future of the Referendum in Australia. Sydney: University of New South Wales Press Ltd. 
Publisher's Note Springer Nature remains neutral with regard to jurisdictional claims in published maps and institutional affiliations.

Nanuli Silagadze is a Ph.D. candidate in Political Science at Åbo Akademi, Finland. Her research interests lie in the field of democratic innovations, in particular, the use of referendums by citizens and political institutions.

Sergiu Gherghina is a Lecturer in Comparative Politics at the Department of Politics, University of Glasgow. His research interests lie in party politics in new democracies (with an emphasis on party organization, recruitment and mobilization), legislative and voting behaviour and democratization. 